\title{
TINGKAT PENGETAHUAN IBU TENTANG PERAWATANLUKA DAN KEJADIAN INFEKSI DAERAH OPERASI DI RSUD BANYUMAS
}

\author{
Utami Purwaningsih ${ }^{1}$, Kris Linggardini ${ }^{2}$ \\ Fakultas Ilmu Kesehatan Program Studi Sarjana Keperawatan Universitas \\ Muhammadiyah Purwokerto \\ Jl. Raya Dukuh Waluh, PO BOX 202, Purwokerto 53182, Kembaran Banyumas, Indonesia \\ utamipurwaningsih72@gmail.com
}

\begin{abstract}
Abstrak
Infeksi daerah operasi adalah infeksi yang terjadi setelah dilakukan tindakan operasi. Pengendalian kejadian infeksi nosokomial adalah bagian dari parameter pelayanan kesehatan yang baik atau tidaknya pada rumah sakit. Ibu yang melahirkan dengan caesar sebanyak satu dari $10 \mathrm{ibu}$ mengalami infeksi. Tingkat pengetahuan pasien tentang cara perawatan luka menjadi faktor penting dalam rangka penurunan angka kejadian infeksi luka daerah operasi pada pasien SC. Tujuan mengetahui hubungan tingkat pengetahuan tentang perawatan luka dengan kejadian infeksi daerah operasi. Desain menggunakan deskriptif korelatif dan pendekatan cross sectional. Sampel sebayak 76 responden. Data penelitian diambil pada bulan Desember 2019 dengan menggunakan kuesioner tingkat penge tahuan dan formulir tanda-tanda infeksi dari morison 2004. Analisa data menggu nak an chi square. Hasil menunjukan terdapat hubungan pengetahuan dengan kejadian infeksi daerah operasi ( $p$ value 0.001 ).

Kata Kunci : Nosokomial, Infeksi Daerah Operasi, Sectio Caesarea
\end{abstract}

\begin{abstract}
Background: Surgical Site Infection is infections that occur after surgery. Control of the incidence of nosocomial infection is part of the parameters of good health services at the hospital. One in 10 mothers who give birth by cesarean has an infection. The level of patient knowledge about how to care for wounds is an important factor in decreasing the incidence of wound infection in the surgical area in SC patients. Objective: knowing the relationship between levels of knowledge of postoperative SC patients about wound care and the incidence of surgical site wound infections. Method: The design used descriptive correlative and cross sectional approach. The sample were 76 respondents. The data were collected in December 2019 by using a knowledg e level que stionnaire and a form of signs of infection from Morison 2004. Data analysis using chi square). The results showed that there was a relationship between knowledge and the incidence of infection in the area of operation ( $p$ value 0.001).
\end{abstract}

Keywords: Nosocomial, Surgical Site Infection (SSI), Section Caesarea (SC)

\section{PENDAHULUAN}

Rumah Sakit merupakan tempat bagi orang yang membutuhkan perawatan untuk proses kesembuhan penyakitnya. Dalam proses perawatan terkadang pasien awal masuk dengan satu penyakit setelah beberapa hari menjalani perawatan pasien mendapatkan penyakit lain. Kondisi ini terjadi karena adanya infeksi selama proses perwatan yang disebut infkesi nosokomial (Darmadi, 2011).

Kejadian infeksi nosokomial merupakan alat ukur kualitas pelayanan kesehatan di rumah sakit. Nosokomial yang tinggi dan tak terkendali merupakan masalah penting dan serius di suatu rumah sakit.
Kondisi tersebut akan berdampak fatal bagi pasien dan merugikan keluarga maupun pasien itu sendiri, dimana kondisi kesehatan pasien akan bertambah buruk dan lama perawatan semakin bertambah sehingga biaya pengobatan semakin besar (Setiy aw ati, 2008 dalam Rosaliya 2011).

Infeksi daerah operasi merupakan suatu kejadian infeksi pada pasien setelah menjalani tindakan operasi (Costy 2013). Hasil penelitian WHO (2013) didapatkan bahwa kejadian infeksi daerah operasi di dunia sebesar 5\%-15\%. NNIS USA menemukan IDO adalah kejadian infeksi peringkat tiga dengan jumlah $14-16 \%$.

Corresponding author:

Utami Purwaningsih

utamipurwaningsih72@gmail.com 
DEPKES RI tahun 2011 menjelaskan bahwa prevalensi kejadian IDO di Pelayanan Kesehatan Pemerintahan sebesar 55,1\%. Salah satunya yaitu kejadian IDO di Rumah Sakit Dr. M. Hoesin Palembang sebesar $56,67 \%$. Kejadian IDO terbilang masih tinggi menjadi perhatian khusus bagi perawat dan dituntut untuk dapat menekan peningkatan angka kejadian tersebut. Upaya yang dapat dilakukan dalam menurunkan dan mencegah terjadinya IDO yaitu memperbaiki sistem pelayanan kesehatan, serta peran dari petugas kesehatan, fasilitas pelayanan kesehatan dan pengunjung pasien. Selain itu, faktor lain yang mendukung terjadinya IDO pada pasien dengan penyakit penyerta seperti pasien dengan diabetes mellitus disebabkan gula darah tidak terkontrol. Hal tersebut dapat dicegah dengan melakukan perbaikan kondisi kesehatan pasien sebelum tindakan operasi seperti mengontrol kada gula darah. Perawat juga berperan dalam menurunkan angka kejadian IDO dengan melakukan perawatan luka sesuai SOP rumah sakit.

Selama proses penyembuhan dan perawatan luka lahitan post operasi caesar memiliki resiko mengalami infeksi (Hardianti, 2014). Hasil penelitian Sheridan (2012) di Inggris menunjukkan ibu yang melahirkan dengan operasi caesar sebanyak 1 dari $10 \mathrm{ibu}$ mengalami infeksi. Ibu dengan kondisi infkesi post SC akan mengalami kesulitan selama merawat bayi dan dibutuhkan durasi lama dalam penyembuhan luka post melahirkan.

Berdasarkan studi pendahuluan pada Mei 2019 yang diperoleh bahwa selama 2018 terdapat 2.035 tindakan operasi dan dari keseluruhan tindakan operasi, 58\% atau 1182 merupakan tindakan operasi SC (Seksio Sesarea). Dari 2.035 tindakan operasi dilaporkan 35 atau $1,67 \%$ pasien post pembedahan mengalami komplikasi pembedahan yaitu Infeksi Daerah Operasi (IDO) dan seluruhnya merupakan pasien dengan tindakan operasi seksio se saria. Jika dibandingkan dengan. Jumlah ini lebih besar dari yang dipersyaratkan indikator mutu RS yaitu dibawah $2 \%$.

Data yang diambil pada rentang awal tahun 2019 juga didapatkan pada bulan januari dari 81 tindakan SC terdapat 2 pasien atau $3,2 \%$ yang mengalami infeksi luka operasi. Sedangkan pada bulan Februari dari 71 tindakan SC dilaporkan 3 pasien atau 4\% mengalami infeksi luka operasi. Proses penyembuhan luka post tindakan operasi dipengaruhi asupan nutrisi, usia, penyakit penyerta, dan pengetahuan pasien, mobilisasi, perawatan luka yang tidak tepat, teknik pembedahan buruk, dan proses pengobatan (Potter and Perry, 2010). Tingkat pengetahuan pasien tentang perawatan luka operasi menjadi salah satu faktor penting dalam rangka penurunan kejadian IDO pasien SC. Tujuan dari penelitian yaitu menganalisis hubungan pengetahuan tentang perawatan luka dengan kejadian infeksi luka operasi (IDO). Pada penelitian ini menjelaskan bagaimana peran pengetahuan pengetahuan tentang perawatan luka dengan kejadian infeksi luka operasi.

\section{METODE PENELITIAN}

Metode yang digunakan diskriptif korelatif dan cross sectional. Populasi dan sampel adalah ibu post sectio caesarea di klinik kebidanan RSUD Banyumas seban yak 76 reponden. Pengambilan data dilakukan dengan menggunkan kuesioner tingkat pengetahuan dan formulir ceklist tanda - tan da infeksi dari Morison 2004. Analisi data menggunakan uji chi square.

\section{HASIL}

1. Gambaran karakteristik responden

\section{Tabel 1}

Distribusi Karakteristik Responden

\begin{tabular}{clcc}
\hline No & Karakteristik & Frekuensi & \% \\
\hline 1 & Umur & & \\
& Remaja & 19 & 25 \\
& Dewasa & 57 & 75 \\
2 & Pendidikan & & \\
& Tidak Sekolah & 0 & 0 \\
& SD & 3 & 3,9 \\
SLTP & 9 & 11,8 \\
SLTA & 27 & 35,5 \\
& DI- DIII & 32 & 42,1 \\
DIV/Sarjana & 5 & 6,6 \\
Pekerjaan & & \\
& Ibu Rumah Tangga & 40 & 52,6 \\
& PNS & 10 & 13,2 \\
& Wiraswasta & 9 & 11,8 \\
& Pegawai Swasta & 10 & 13,2 \\
& Tani & 4 & 5,3 \\
& Buruh & 3 & 3,9 \\
\hline & & &
\end{tabular}

Tabel 1 menjelaskan bahwa umur responden paling banyak masuk kategori dewasa yaitu sebanyak 57 (75\%), sedangkan pendidikan paling banyak 
responden diploma sebanyak $32(42,1 \%)$. Pekerjaan sebagian besarmerupakan IRT yaitu sebanyak $40(52,6 \%)$.

2. Pengetahuan responden

Tabel 2

Pengetahuan Respoden

\begin{tabular}{lcc}
\hline Tingkat Pengetahuan & Frek & \% \\
\hline Kurang & 6 & 7,9 \\
Cukup & 47 & 61,8 \\
Baik & 23 & 30,3 \\
\hline Total & $\mathbf{7 6}$ & $\mathbf{1 0 0}$ \\
\hline
\end{tabular}

Tabel 2 menjelaskan bahwa tingkat pengetahuan didominasi oleh pengetahuan cukup sebanyak 47 orang $(61,8 \%)$.

3. Gambaran status infeksi responden post operasi sectio caesarea

Tabel 3

Gambaran Status Infeksi Responden Post Operasi Sectio Caesarea

\begin{tabular}{lcc}
\hline \multicolumn{1}{c}{ Status Infeksi } & Frek & \% \\
\hline Tidak Infeksi & 43 & 56,6 \\
Infeksi & 33 & 43,4 \\
\hline Total & $\mathbf{7 6}$ & $\mathbf{1 0 0}$ \\
\hline
\end{tabular}

Tabel 3 menjelaskan bahwa pasien didominasi tidak mengalami infeksi daerah operasi sebanyak $43(56,6 \%)$ dan 33 responden $(43,4 \%)$ mengalami infeksi luka daerah operasi.

Hasil penelitian menunjukan bahwa keseluruhan (100\%) dari 6 responden dengan tingkat pengetahuan Kurang mengalami infeksi luka daerah operasi, sebaliknya responden dengan tingkat pengetahuan Baik hampir keseluruhan yaitu 19 orang $(82,6 \%)$ dari 23 orang tidak mengalami infeksi daerah operasi. Sedangkan responden dengan tingkat pengetahuan Cukup sebagian besar tidak mengalami infeksi daerah operasi yaitu sebanyak 24 orang (68\%) dari 47 orang. Hasil analisa statistik didapatkan hasil p 0.001 artinya terdapat hubungan signifikan tingkat pengetahuan dengan kejadian infeksi luka daerah operasi.

\section{PEMBAHASAN}

Pengetahuan ibu dapat dikategorikan baik sebanyak 23 responden (30,3\%). Notoatmodjo (2010) menjelaskan bahwa pengetahuan seseorang merupakan hasil tahu yang dilalui serta diamati oleh seseorang dengan proses penginderaan pada suatu objek. Proses penginderaan pada suatu objek terjadi melalui sistem panca indra seperti melihat, mendengar, penciuman, perasa, dan peraba. Pengetahuan seseorang cenderung paling banyak didapatkan melalui mata dan telinga. Tingkat pengetahuan individu ditentukan dari aspek tingkat pendidikan, pengalaman, budaya, informasi serta sosial ekonomi.

Gambaran status infeksi daerah operasi pada 76 pasien post operasi di RSUD Banyumas menunjukan sebagian besar responden sebanyak 43 orang $(56,6 \%)$ tidak mengalami infeksi daerah operasi, sisanya 33 responden $(43,3 \%)$ tidak menunjukan tand atanda infeksi daerah operasi. Hasil penelitian yang dilakukan menunjukan keseluruhan $(100 \%)$ responden dengan tingkat pengetahuan kurang, mengalami infeksi luka daerah operasi. Responden dengan tingkat pengetahunan Cukup, menunjukan sebagian besar yaitu 24 orang $(51,1 \%)$ tidak mengalami infeksi luka operasi. Hanya sebagian kecil dari reponden dengan tingkat pengetahuan Baik yg menglami infeksi luka daerah operasi yaitu 4 orang $(17,4 \%)$.

Hasil analisa bivariat antara tingkat pengetahuan dengan kejadian infeksi luka daerah operasi menunjukan $p 0.001$, artinya terdapat hubungan signifikan pengetahuan dengan kejadian infeksi luka derah operasi. Hasil penelitian didukung penelitian Novelia (2013) menunjukkan bahwa tingkat pengetahuan tentang perawatan luka ibu nifas SC berhubungan dengan kejadian IDO.

Responden dengan tingkat pengetahuan yang rendah tentang perawatan luka post oprasi menunjukan frekuensi kejadian infeksi luka operasi yang lebih besar. Menurut Winarni (2011), upaya dalam pencegahan trauma pada kulit, membrane mukosa dan jaringan lainnya pada pasien post operasi SC maka perlu dilakukan perawatan luka jahitan. Tindakan ini dilakukan dengan maksud pencegahan terjadinya infeksi atau masuknya mikroorganisme kedalam luka. Pada perawatan luka jahit juga dimaksudkan adanya eksudat atau nanah yang kemudian dikeluarkan dengan tujuan luka cepat dalam proses penyembuhan dan infkesi tidak sampai menyebar luas. Menurut penulis, kurangnya pengetahuan responden tentang perawatan luka membuat beebagai faktor pendukung kesembuhan luka tidak terpenuhi sehingga angka kejadian infeksi menjadi lebih tinggi. 
Sedangkan tingginya pemahaman tentang perawatan luka dan faktor-faktor yang mempengaruhi kesembuhan luka oleh responden membuat semua faktor penyebab infeksi dapat tereliminasi.

\section{KESIMPULAN}

Pengetahuan ibu kategori cukup tentang perawatan luka post operasi sectio caesarea yaitu sebanyak 47 orang $(61,8 \%)$. Sebagian besar responden tidak mengalami infeksi daerah operasi sectio caesarea yaitu sebanyak 43 orang $(56,6 \%)$. Ada hubungan pengetahuan ibu tentang perawatan luka dengan kejadian infeksi luka daerah operasi di RSUD Banyumas dengan $p$ value $0.001(<0.05)$.

Disarankan perlunya kesadaran dan kemauan meningkatkan pengetahuan tentang perawatan luka. Dengan menggali informasi lebih mendalam tentang perawatan luka operasi dan faktor-faktor yang mendukung untuk mempercepat kesembuhan luka diharapkan dapat mencegah terjadinya infeksi daerah operasi. Perlunya peningkatan lay anan promotif dan edukasi kepada pasien yang efektif sehingga angka kejadian infeksi daerah operasi (IDO) khusunya pasien dengan operasi sectio caesarea dapat semakin ditekan.

Implikasi dari hasil penelitian ini yaitu infeksi pada daerah luka operasi merupakan suatu masalah yang diperlukan pencegahan sehingga tidak sampai terjadi. Pencegahan dilakukan dengan melakukan perawatan yang baik dan benar. Perawatan yang baik dan benar ini ditunjang dengan pengetahuan tentang perawatan luka oleh pasien maupun keluarga.

\section{DAFTAR PUSTAKA}

Costy P. (2013). Simposium Ilmiah Teknologi Mutakhir sebagai Perlindungan dari Kuman dan Perannya dalam Mencegah Infeksi Nosokomial. Jakarta.
Hardianti, M. (2014). Tanda Infeksi Jahitan Operasi Caesar. http://www.vemale.com.

Darmadi. (2011). Infeksi Nosokomial Problematika dan Pengendalianya. Jakarta: Salemba Medika.

Notoatmodjo. (2010). Promosi Kesehatan Teori dan Aplikasi. Jakarta: Rineka Cipta.

Novelia. (2013). Tingkat Pengetahuan Ibu Nifas Post Sectio Cesarea Tentang Perawatan Luka Post Sectio Cesarea di RSB Fitri Candra Wonogiri Tahun 2013. Karya Tulis Ilmiah. STIKES Kusuma Husada Surakarta.

Potter dan Perry. (2010). Buku Ajar Fundamental Keperawatan. Jakarta: EGC.

Rosaliya. (2011). Faktor-faktor yang Mempengaruhi Kejadian Infeksi Nosokomial pada pasien Luka Post Operasi di RSUD Tugurejo. Jurnal Kesehatan.

Sheridan. (2012). Risk factors for surgical site infection following caesarean section in England : results from a multicentre cohort study. BJOG An international Journal of Obstetrics and Gynaecology. London : Health protection agency UK.

WHO. (2013). Surgical wound infection. WHO.

Winarni L. M.. (2011). Perawatan Luka Operasi Sesar Sectio Caesarea: Diakses pada 22 Agustus 2020 dari http://materikebidanan.word pressc. 